\title{
Pelatihan aplikasi perkantoran untuk meningkatkan keterampilan kader Posyandu Anyelir 8 Perumnas Antang Kota Makassar
}

\section{Nuraida Latif ${ }^{1 *}$, Muhajirin ${ }^{2}$, Mashud $^{3}$, Ramlah $\mathbf{P}^{4}$, Markani ${ }^{5}$, Neneng Awaliah ${ }^{6}$, Butsiarah 7}

\author{
1,2,7 Teknik Informatika, STMIK AKBA, Makassar \\ 3,4,5,6 Sistem Informasi, STMIK AKBA
}

nuraida@akba.ac.id

\begin{abstract}
Posyandu is the center of community activities in the effort to provide health services and family planning. These trained Posyandu cadres are not only seen from the way they handle maternal and child health but also have to be supported by their ability to use computers in administrative management and data processing. The method used in this community service activity is a combination of tutorials, practice, and discussion or question and answer, as well as evaluation to determine the level of absorption of the training material. The office application materials provided are Microsoft word, Microsoft excel, and Microsoft powerpoint. Office application program training activities for cadres of Posyandu Anyelir 8 Block 8 Perumnas Antang were carried out well and improved the skills of Posyandu Anyelir 8 Block 8 Perumnas cadres in the use of information technology.
\end{abstract}

Keywords: Cadre, Posyandu, Community Service, Training.

\begin{abstract}
Abstrak
Posyandu merupakan pusat kegiatan masyarakat dalam upaya pelayanan kesehatan dan keluarga berancana. Kader Posyandu yang terlatih ini tidak hanya terlihat dari cara penanganan mereka terhadap kesehatan ibu dan anak namun juga harus didukung oleh kemampuan mereka dalam menggunakan komputer dalam pengelolaan administrasi dan pengolahan data. Metode yang digunakan pada kegiatan pengabdian masyarakat ini adalah kombinasi dari tutorial, praktek, dan diskusi atau tanya jawab, serta evaluasi untuk mengetahui tingkat penyerapan terhadap materi pelatihan. Materi aplikasi perkantoran yang diberikan adalah Microsoft word, Microsoft excel, dan Microsoft powerpoint. Kegiatan pelatihan program aplikasi perkantoran kepada kader Posyandu Anyelir 8 Blok 8 Perumnas Antang terlaksana dengan baik dan meningkatkan keterampilan kader Posyandu Anyelir 8 Blok 8 Perumnas dalam penggunaan teknologi informasi.
\end{abstract}

Kata Kunci: Kader, Posyandu, Pengabdian Masyarakat, Pelatihan.

\section{PENDAHULUAN}

Aplikasi Microsoft Office merupakan salah satu aplikasi yang banyak digunakan dalam mengolah data. Dalam Microsoft Office ada beberapa aplikasi yang biasanya di gunakan yaitu Microsoft Word, Microsoft Excel, Microsoft PowerPoint. Microsoft Word adalah sebuah program pengolah kata (word prosessor), lebih tepatnya sebuah program untuk membuat surat, buku, brosur dan lain-lain, Microsof Excel merupakan program spreadsheet yang banyak digunakan saat ini. Dengan menggunakan Microsof Excel dapat meyelesaikan perhitungan dan analis data, sedangkan Microsoft PowerPoint 
adalah satu aplikasi komputer yang difokuskan pembuatan presentasi. (Ashari, Markani \& Mashud, 2019). Aplikasi ini banyak di gunakan mulai dari perkantoran sampai ke posyandu dalam pengolahan data.

Posyandu merupakan salah satu bentuk Upaya Kesehatan Bersumber Daya Masyarakat (UKBM) yang dikelola dan diselenggarakan dari, oleh, untuk dan bersama masyarakat dalam penyelenggaraan pembangunan kesehatan, guna memberdayakan masyarakat dan memberikan kemudahan kepada masyarakat dalam memperoleh pelayanan kesehatan dasar untuk mempercepat penurunan angka kematian ibu dan bayi. UKBM adalah wahana pemberdayaan masyarakat, yang dibentuk atas dasar kebutuhan masyarakat, dikelola oleh, dari, untuk dan bersama masyarakat, dengan bimbingan dari petugas Puskesmas, lintas sektor dan lembaga terkait lainnya (Kemenkes RI, 2011).

Kegiatan posyandu tidak terbatas hanya pemberian imunisasi saja, tetapi juga memonitor tumbuh kembang bayi dan balita melalui kegiatan penimbangan dan pemberian makanan tambahan. Pencegahan dan penanganan gizi buruk juga dapat segera ditangani sedini mungkin jika posyandu berjalan baik, karena pada dasarnya anak balita bergizi buruk tidak semua lahir dalam keadaan berat badan tidak normal (Soegianto, 2005)

Posyandu Anyelir 8 adalah salah satu posyandu yang ada di Kota Makassar tepatnya di Blok 8 Perumnas Antang Kota Makassar. Berdasarkan komunikasi dengan Ketua RW 8 Perumnas Antang Kelurahan Manggala, Kecamatan Manggala, Kota Makassar dan Kader Posyandu bahwa mereka memiliki keterbatasan dalam penguasaan teknologi khususnya teknologi informasi, sehingga kegiatan administrasi pada Posyandu Anyelir 8 Blok 8 Perumnas Antang masih menggunakan proses manual. Hal ini dinilai sangat merepotkan oleh para kader posyandu. Banyaknya kegiatan yang dilaksanakan di posyandu harus diiringi dengan keterampilan untuk melakukan pendataan dan menyusun laporan kegiatan dengan cepat dan rapi. Berangkat dari alasan tersebut, tim dosen dari STMIK AKBA, melaksanakan kegiatan pengabdian masyarakat pelatihan aplikasi perkantoran khususnya Microsoft Word, Microsoft Excel dan Microsoft Power Point untuk meningkatkan keahlian para kader Posyandu Anyelir 8 Blok 8 Perumnas Antang dalam penguasaan teknologi informasi.

\section{METODE PELAKSANAAN}

\subsection{Peserta Pelatihan}

Pelaksanaan kegiatan pengabdian masyarakat dengan memberikan pelatihan program apilasi perkantoran yang diikuti oleh 12 orang kader Posyandu Anyelir 8 Blok 8 Perumnas Antang, Makassar.

\subsection{Lokasi dan Waktu}

Pelatihan program aplikasi perkantoran dilaksanakan pada 27 Juli 2019 di Posyandu Anyelir 8 Blok 8 Perumnas Antang Kelurahan Manggala, Kecamatan Manggala, Kota Makassar. 
Metode yang digunakan pada kegiatan ini adalah kombinasi dari tutorial, praktek, dan diskusi atau tanya jawab, serta evaluasi untuk mengetahui tingkat penyerapan terhadap materi pelatihan aplikasi perkantoran yang diberikan. Program aplikasi perkantoran yang menjadi materi pelatihan:

1. Microsof word

2. Microsof Excel

3. Microsoft Power Point

Tahap-tahap yang dilakukan untuk merealisasikan kegiatan pelatihan aplikasi perkantoran ini adalah:

1. Tahapan Pendahuluan

Mempersiapkan perlengkapan pelatihan. Perlengkapan pelatihan yang dipersiapkan seperti layar, proyektor, laptop peserta dan lain-lain

2. Tahapan Pelaksanaan

Memberikan pemaparan materi dan praktek yaitu:

a. Pemaparan tentang program aplikasi perkantoran.

Materi berisi pengenalan program apilasi perkantoran secara umum.

b. Pengenalan dan praktek microsoft word

1) Menjelaskan tetang microsoft word dan angkah demi langkah dalam memulai menggunakan Microsoft word.

2) Mengerjakan langsung soal-soal yang dikerjakan ke dalam tugas administrasi perkantoran surat-menyurat dengan menggunakan Microsoft Word

3) Diskusi dan tanya jawab peserta pelatihan.

c. Pengenalan dan praktek microsoft Excel

1) Menjelaskan tetang microsoft excel dan angkah demi langkah dalam memulai menggunakan Microsoft excel.

2) Membuat tabel-tabel yang diikuti dengan pelatihan rumus-rumus yang ada di aplikasi Microsoft Excel

3) Diskusi dan tanya jawab peserta pelatihan.

d. Pengenalan dan praktek microsoft Excel

1) Menjelaskan tetang microsoft power point dan angkah demi langkah dalam memulai menggunakan Microsoft power point.

2) Membuat bahan persentasi mengenai bahan penyuluhan yang akan digunakan sewaktu dibutuhkan dalam penyuluhan

3) Diskusi dan tanya jawab peserta pelatihan.

3. Tahapan Evaluasi

Evaluasi yang diberikan kepada peserta adalah melihat hasil akhir praktek yang telah dilakukan oleh peserta lalu memberikan masukan-masukan kepada peserta. 


\section{HASIL DAN PEMBAHASAN}

Kegiatan pengabdian kepada masyarakat berupa Pelatihan Aplikasi Perkantoran dilaksanakan oleh tim dosen dari STMIK AKBA. Dengan pelatihan ini diharapkan peserta dapat menambah keterampilan dalam mengoperasikan aplikasi perkantoran untuk kegiatan administratif mereka dalam bekerja nantinya.

Beberapa faktor pendukung kegiatan pelatihan ini antara lain para peserta pelatihan memiliki antusias yang tinggi untuk mengikuti kegiatan. Para kader Posyandu Anyelir 8 sangat mendukung terselenggaranya kegiatan pelatihan ini dengan menyediakan fasilitas yang cukup memadai, seperti ruang pelatihan dan beberapa laptop untuk peserta.

Kegiatan pengabdian masyarakat yang dilakukan di bertempat di Posyandu Anyelir 8 Blok 8 Perumnas Antang berjalan sesuai rencana kegiatan. Pertama persiapan proyektor dan laptop peserta, seperti pada pada gambar 1 dan gambar 2 .

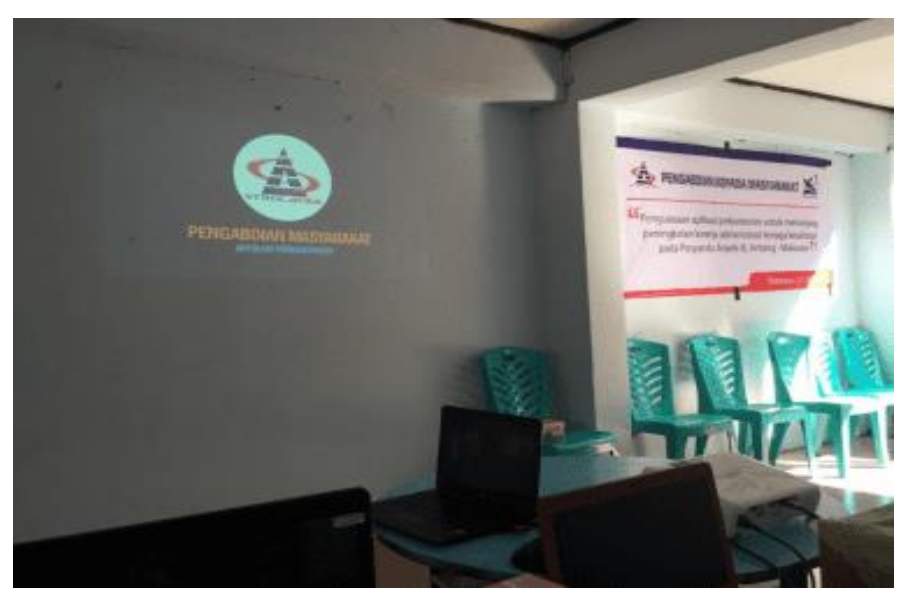

Gambar 1. Persiapan Proyektor

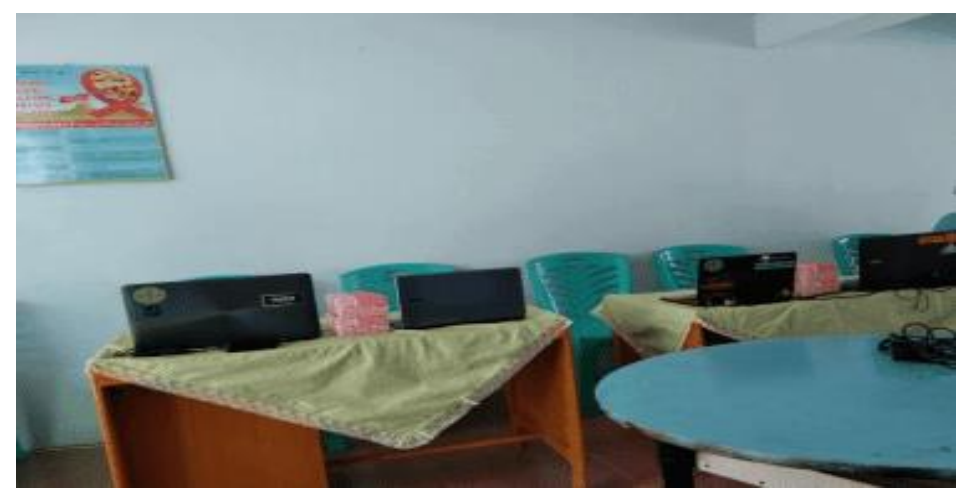

Gambar 2. Persiapan Laptop Peserta

Setelah proyektor dan laptop sudah siap maka tahap selanjutnya pemberian materi oleh dosen anggota pelaksana pengabdian masayarakat gambar 3 dan gambar 4 . 


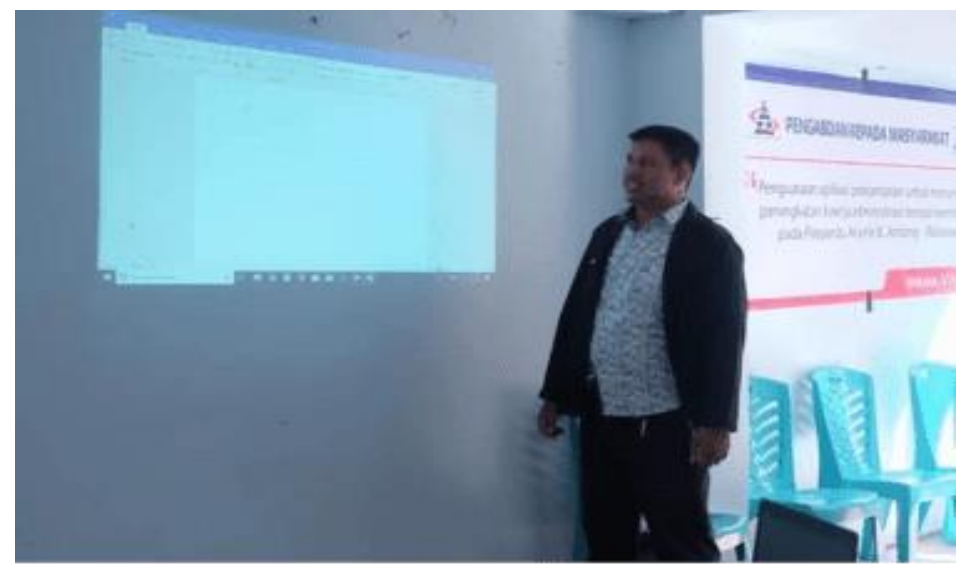

Gambar 3. Materi Microsoft Word

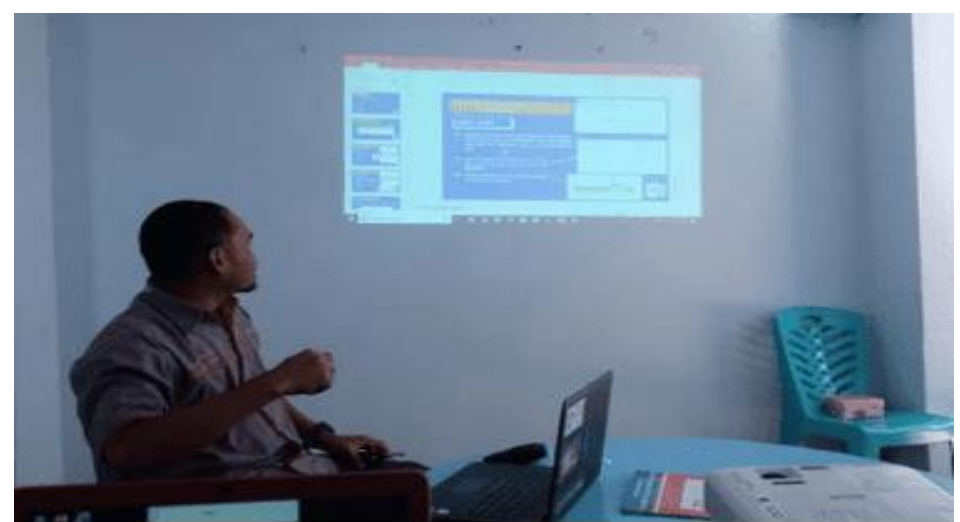

Gambar 4. Materi Power Point

Pada proses praktikum peserta juga didampingi oleh tim dosen pelaksana pendabdian dan mahsiswa yang iktu serta dalam kegiatan ini. Pendamping melayani peserta yang terhambat atau ada kendala dalam kegiatan praktikum seperti ppada gambar 5 .

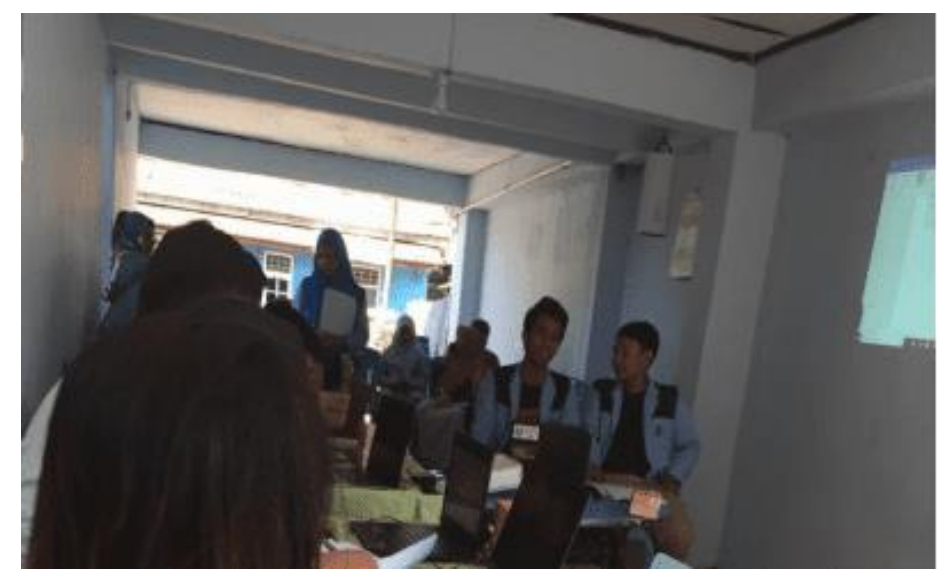

Gambar 5. Mahasiswa STMIK AKBA yang ikut dalam kegiatan

Setelah peserta menyelesaikan praktikum, dilakukan evaluasi yang diberikan kepada peserta adalah melihat hasil akhir praktek yang telah dilakukan oleh peserta lalu memberikan masukan-masukan kepada peserta. 


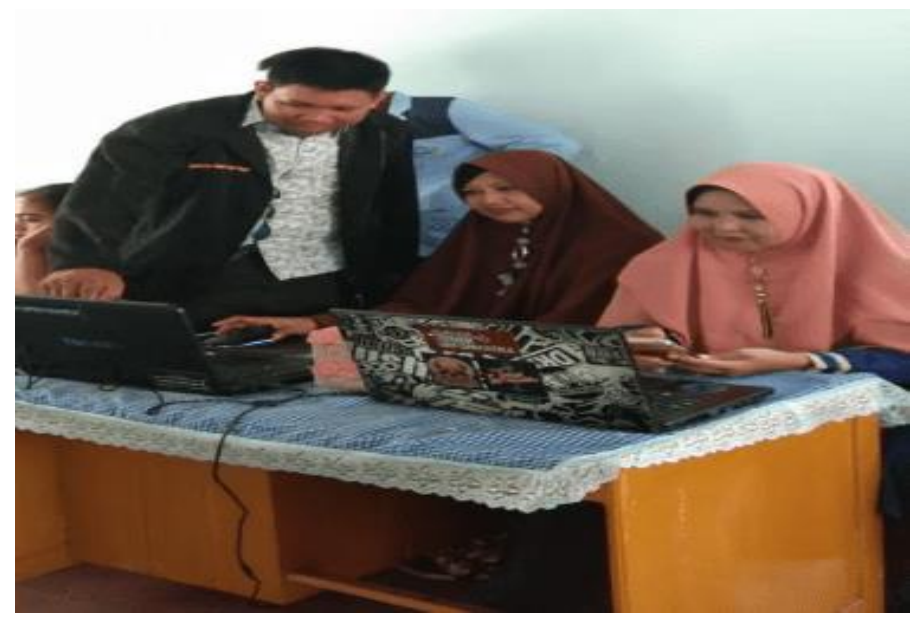

Gambar 6. Evaluasi hasil praktikum

Di akhir peltaihan di lakukan pemberian sertifikat kepada peserta dan foto Bersama, seperti pada gambar 7.

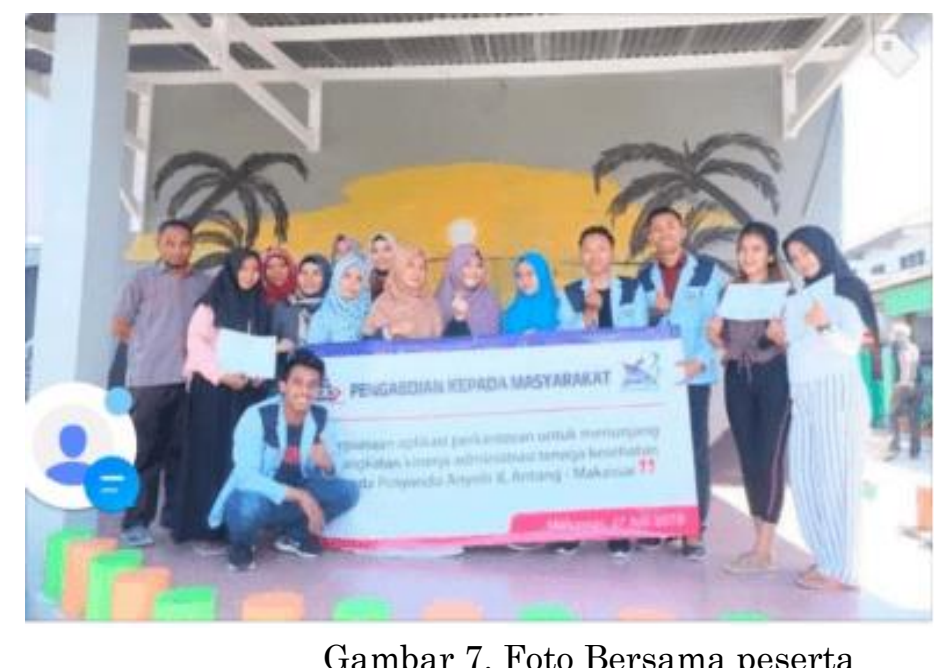

\section{SIMPULAN}

Berdasarkan pemaparan hasil pelaksanaan kegiatan ini maka dapat disimpulkan bahwa kegiatan berupa pelatihan program aplikasi perkantoran kepada kader Posyandu Anyelir 8 Blok 8 Perumnas Antang terlaksana dengan baik. Kegiatan ini disambut dan diterima dengan baik oleh ketua RW dan kader posyandu sehingga mereka memahami bagaimana efektifitas pengelolaan administrasi danpengolahan data bisa dicapai dengan menggunakan sentuhan program teknologi komputer bisa mencapai tujuan yang lebih dari yang ditargetkan dengan mudah.

Rekomendasi dari pelatihan pengabdian masysrakat berupa pelatihan aplikasi perkantoran bagi kader Posyandu Anyelir 8 Perumnas Antang masih perlu di adakan lagi pelatihan Kembali dan pendampingan terutamanya bagi materi-materi yang lebih sulit dipahami agar nanti dalam pengoperasikan mocrosoft office menjadi lebih baik 
sehingga akan meningkatkan keterampilan dari keder poyandu dalam melayani masyarakat.

\section{UCAPAN TERIMA KASIH}

Ucapan terima kasih kepada Lembaga Penelitian dan Pengabdian Kepada Masyarakat (P3M) STMIK AKBA yang telah mendanai kegiatan pengabdian kepada masyarakat di Posyandu Anyelir 8 Perumnas Antang, sehingga kegiatan pengabdian ini dapat berjalan dengan baik. Juga kepada Kader Posyandu Anyelir 8 Perumnas Antang atas kesediannya menerima tim pengabdian dari STMIK AKBA

\section{REFERENSI}

Arifin, R., \& Latif, N. (2020). Sistem Informasi Pengelolaan Surat Menyurat Berbasis Web Pada Kantor Balai Latihan Masyarakat Makassar. Inspiration: Jurnal Teknologi Informasi dan Komunikasi, 10(1), 68-76.

Ashari, M. \& Mashud (2019). Program Aplikasi Perkantoran. I ed. Makassar: Rayhan Intermedia.

Latif, N., Disa, S., Ratnawati, R., Halid, A., Sumardin, A., Muniar, A. Y., \& Wisda, W. (2021). Pelatihan Pemanfaatan Sistem Informasi Pelaporan Retribusi Sampah. Jurnal Abdidas, 2(4), 737-742.

Kementerian, K. R. (2011). Pedoman Umum Pengolahan Posyandu. I ed. Jakarta: Kemenkes RI.

Syamsu, S., Ramlah, P., \& Muniar, A. Y. (2021). Pelatihan Pemanfaatan Google Form Pada Aparat dan Perangkat Desa Kurusumange, Kecamatan Tanralili, Kabupaten Maros. JPEMAS-Jurnal Pengabdian Masyarakat, 2(2), 37-44. 